\title{
The Influence of Steel Fibers Extracted from Waste Tyre on Properties of Concrete Containing Fly Ash
}

\author{
Fauzan $^{\#}$, Febrin Anas Ismail ${ }^{\#}$, Rio Sandi ${ }^{\#}$, Zev Al Jauhari ${ }^{\#}$ \\ \# Department of Civil Engineering, Andalas University, Padang City, 25163, Indonesia \\ E-mail:fauzanrn@yahoo.com,fauzan@ft.unand.ac.id
}

\begin{abstract}
This article presents the result of an experimental study carried out to investigate the effect of steel fibers extracted from the waste tyre (SFEFWT) on concrete containing fly ash. Steel fibers are extracted from waste tyres by the manual cutting process and cut to 1 inch $(25.4 \mathrm{~mm})$ length. A number of cylindrical specimens of concrete containing $15 \%$ fly ash by replacing cement weight, by having an addition $0 \%, 0.25 \%, 0.5 \%, 0.75 \%, 1 \%$ SFEFWT are casted and tested. The mechanical properties: compressive, tensile and flexural strengths at the age of 28 days are studied for having prepared the concrete. The results show that compressive, tensile and flexural strengths are positively affected by the addition of SFEFWT on the concrete containing fly ash. In addition, more percentage of SFEFWT content on the concrete containing fly ash will give high results for its strength and bonding. Then, the bonding delays the crack growth.
\end{abstract}

Keywords - concrete; steel fiber; waste tyre; fly ash; compressive strength; tensile strength; flexural strength

\section{INTRODUCTION}

It has been known that there are many deficit characteristics of concrete which limits its applications, example; concrete has a low stiffness, ductility, and energy absorption. Furthermore, when concrete becomes hardened, shrinkage cracks appear on its surface. In order to improve these deficiencies in concrete, nowadays, a variety of fiber materials is used in concrete to improve its applications for the best services. The fibers, such as steel, glass, polymeric, natural and plastic fibers are mixed with the concrete at particular length and specified aspect ratio and randomly distributed. Thus, those can effectively be utilized to overwhelm such deficits.

The addition of fibers to concrete considerably improves its structural characteristics such as static flexure, impact, tensile strength, ductility, and flexural toughness [1]. Steel fiber reinforced can improve the fracture toughness, mechanical properties, and durability related properties of the concrete [2]. The inclusion of steel fibers in concrete considerably enhanced the engineering properties of mortar and concrete [3]. The steel fibers have effected on compressive, tensile, flexural strength, modulus of elasticity and ultrasonic pulse velocity of steel fiber self-compacting concrete. The strength increases as the fiber content increased [4], [5]. Using a little percentage of steel fibers efficiently improves the load-carrying capability of slabs on ground, and it significantly improves the slab ductility [6]. With the inclusion of hooked steel fibers with $6 \mathrm{~cm}$ cut length, 80 aspect ratio, and replacement of cement with $0.5 \%$ and $1 \%$ improve the mechanical properties of concrete [7]. The addition of steel fibers prevents internal micro-cracks of concrete. A major enhancement in the energy absorption and ductility in compression is observed by addition fibers at concrete [8]. The results of ultrasonic pulse velocity reveal which use small percentages of steel fiber in the concrete improve its quality [9].

The use of cement replacement materials (CRM) from thermal industry waste such as fly ash in the concrete has many advantages. It will be several impacts on environmental benefits, and thus it is eco-friendly. In addition, cement replacement with fly ash will help to reduce the cost of construction. The addition of ultra-fine fly ash (UFA) to cement paste, mortar, and concrete can improve their fluidity, but some coarse fly ash cannot reduce water $[10,11]$. The use of fly ash in concrete is found to affect strength characteristics adversely at an early age. One of the ways to compensate for the early-age strength loss associated with the usage of fly ash by incorporating fibers, which have been proved that it is very efficient to enhance the strength characteristics of concrete [12], [13], [14].

In Indonesia, more than 50 million waste tyres are generated per year. However, materials in waste tyre such as textile and steel fibers, actually, can be used to improve the mechanical properties of the concrete. Some researchers have studied the effect of the recycled steel fibers on normal concrete. The recycled steel fibers reinforced concrete (RSFRC) gives more improvement in the concrete strength [15], [16]. However, there has not been studied previously 
the effect of steel fibers from the recycled tyre on partial properties replacement of fly ash on the concrete.

In this study, the effect of steel fiber extracted from the waste tyre on mechanical properties of concrete containing fly ash is investigated. The concrete containing fly ash is hereafter called as fly ash concrete.

\section{MATERIALS AND METHOD}

\section{A. Materials Used}

1) Cement: Ordinary Portland Cement (OPC), which is commonly available in the market, is used in this study.

2) Fine and Coarse Aggregates: Locally available aggregates are used; fine aggregate with size retained on 200 number sieves and passed from $4.75 \mathrm{~mm}$. The specific gravity of fine aggregate is 2.57 . The coarse aggregate used is locally available quarry having two different sizes; one fraction is passing through $20 \mathrm{~mm}$ sieve, and another fraction is passing through $10 \mathrm{~mm}$ sieve. The specific gravity of $20 \mathrm{~mm}$ and $10 \mathrm{~mm}$ aggregates are respectively 2.70 and 2.60 .

3) Water: Potable tap water is used in mix preparation.

4) Steel Fiber Extracted From Waste Tyre: Waste tyres in Indonesia are the low and economical price and in abundance available material. In Indonesia, the utilization of waste tyre is very rare, and it becomes a pollution problem. Therefore, the utilization of waste tyre is done in this research. In this study, the steel fibers taken out from waste tyres (Fig. 1) are used in the concrete mix to form a composite fibrous material. Steel fibers waste tyre are extracted from chips of waste tyres by the manual cutting process (Figs. 2 and 3 ) and cut to 1 inch $(25.4 \mathrm{~mm})$ length (Fig. 4), and an average diameter of the fiber is $0.28 \mathrm{~mm}$ keeping aspect ratio 90. As waste tyres steel fibers are uniformly and randomly distributed in different proportions from $0-1 \%$ with an increment of $0.25 \%$ by the volume of concrete to prepare the different concrete matrix. The chips of waste tyres are available in the local market; normally they sell those as scrap to scarp industry.

5) Fly Ash: Fly Ash obtained from Ombilin coal power plant at Sawahlunto, West Sumatera, Indonesia, is used in this study (Fig. 5). The specific gravity of fly ash is 2.30 . The chemical composition of fly ash is tested in Indarung II, Padang Cement Indonesian Factory. The result is given in Table 1.

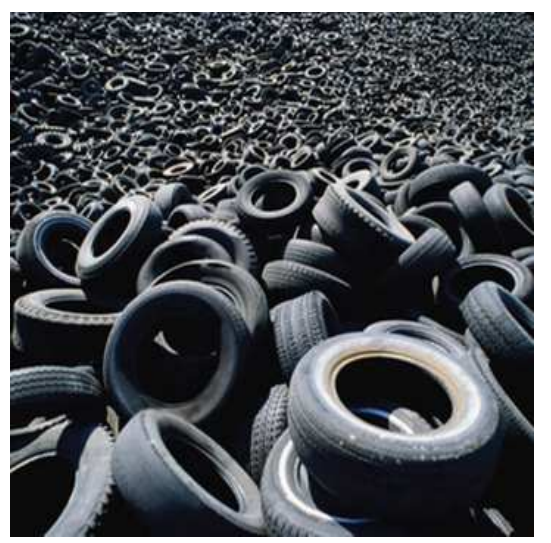

Fig. 1 Waste tyre

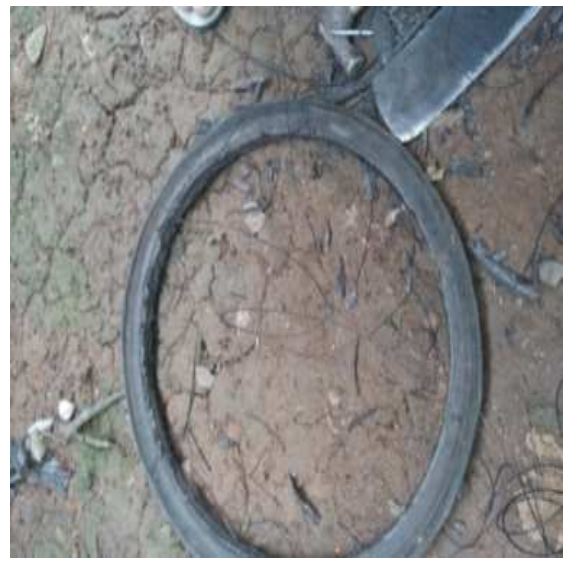

Fig. 2 Cutting process from waste tyre to obtain extracted steel fiber

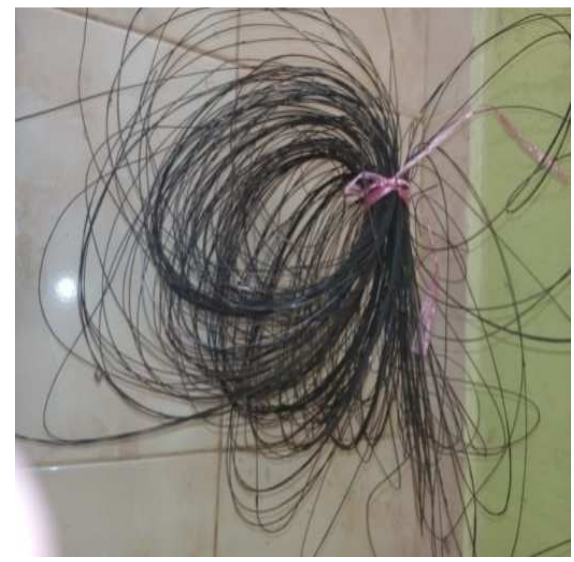

Fig. 3 Steel fiber extracted from waste tyre

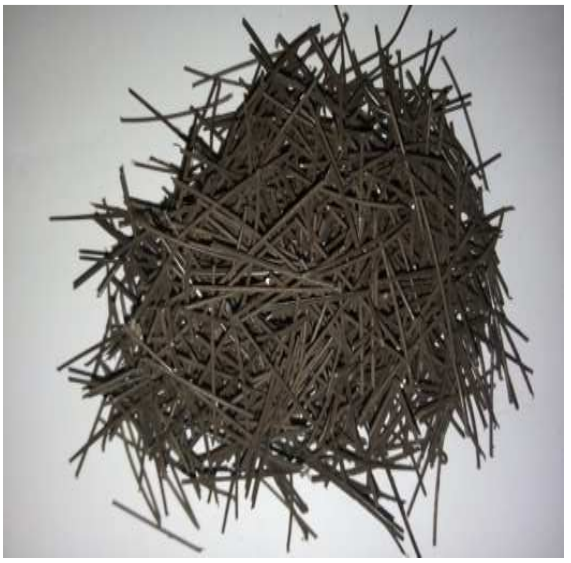

Fig. 4 The 1 inch length of steel fiber extracted from waste tyre

\section{B. Experimental Program}

1) Mix Proportions of Concrete: The concrete mix is designed based on Indonesian National Standard (SNI) for the normal concrete. The grade of adopted concrete is M35 with a water-cement ratio of 0.52 . Six mixture proportions are created. The first is control mix (concrete without fly ash and steel fibers), and the other five mixes are fly ash concrete with steel fiber, with the percentage of $0 \%, 0.25 \%$, $0.5 \%, 0.75 \%$, and $1 \%$ by volume of concrete.

The cement is partially replaced with fly ash. The proportion of cement is replaced $15 \%$ by weight. The 
ingredients of concrete are thoroughly mixed in a mixer machine until the uniform consistency achieved. Mix proportions are given in Table 2.

2) The casting of Specimens: Total 45 specimens are cast. They consist of 30 cylinder specimens of length 300 $\mathrm{mm}$ and diameter $150 \mathrm{~mm}$ for compressive and tensile tests and 15 beams specimens of length $500 \mathrm{~mm}$, wide $100 \mathrm{~mm}$ and high $100 \mathrm{~mm}$ for the flexural strength test. Cylindrical and beam specimens are cast with $0 \%, 0.25 \%, 0.5 \%, 0.75 \%$ and $1 \%$ content of used waste tyre extracted steel fibers in the concrete containing fly ash.

TABLE I

CHEMICAL COMPOSITION OF FLY ASH

\begin{tabular}{|c|c|c|}
\hline $\begin{array}{c}\text { Chemical } \\
\text { Composition }\end{array}$ & Formulae & (\%) Content \\
\hline Silicon Dioxide & $\mathrm{SiO}_{2}$ & 54.90 \\
\hline Aluminium Trioxide & $\mathrm{Al}_{2} \mathrm{O}_{3}$ & 26.83 \\
\hline Iron Oxide & $\mathrm{Fe}_{2} \mathrm{O}_{3}$ & 6.94 \\
\hline Lime & $\mathrm{CaO}$ & 4.05 \\
\hline Magnesium Oxide & $\mathrm{MgO}$ & 0.74 \\
\hline Potassium Oxide & $\mathrm{K} 2 \mathrm{O}$ & - \\
\hline Loss of Ignition & $\mathrm{LOI}$ & - \\
\hline
\end{tabular}

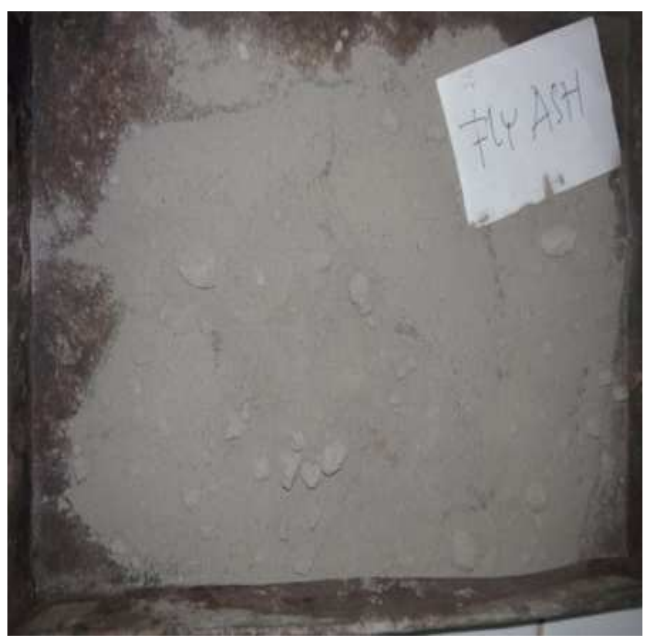

Fig. 5 Fly ash

TABLE II

MIX PROPORTIONS

\begin{tabular}{|c|c|c|c|c|c|c|}
\hline $\begin{array}{l}\text { Sample } \\
\text { ID }\end{array}$ & $\mathrm{C}$ & $\begin{array}{c}\text { SFEF } \\
\text { WT } \\
0\end{array}$ & $\begin{array}{c}\text { SFEF } \\
\text { WT } \\
0.25 \\
\end{array}$ & $\begin{array}{c}\text { SFEF } \\
\text { WT } \\
0.50\end{array}$ & $\begin{array}{c}\text { SFEF } \\
\text { WT } \\
0.75\end{array}$ & $\begin{array}{c}\text { SFEF } \\
\text { WT } \\
1\end{array}$ \\
\hline $\begin{array}{l}\text { Cement } \\
\left(\mathrm{kg} / \mathrm{m}^{3}\right)\end{array}$ & 391 & $\begin{array}{c}332.3 \\
5 \\
\end{array}$ & $\begin{array}{c}332.3 \\
5 \\
\end{array}$ & $\begin{array}{c}332.3 \\
5 \\
\end{array}$ & $\begin{array}{c}332.3 \\
5 \\
\end{array}$ & $\begin{array}{c}332.3 \\
5 \\
\end{array}$ \\
\hline $\begin{array}{l}\text { Water } \\
\left(\mathrm{kg} / \mathrm{m}^{3}\right)\end{array}$ & 205 & 205 & 205 & 205 & 205 & 205 \\
\hline $\begin{array}{l}\text { F.A. } \\
\left(\mathrm{kg} / \mathrm{m}^{3}\right)\end{array}$ & $\begin{array}{c}725 . \\
6 \\
\end{array}$ & 725.6 & 725.6 & 725.6 & 725.6 & 725.6 \\
\hline $\begin{array}{l}\text { C.A. } \\
\left(\mathrm{kg} / \mathrm{m}^{3}\right)\end{array}$ & $\begin{array}{l}108 \\
8.4\end{array}$ & $\begin{array}{c}1088 . \\
4\end{array}$ & $\begin{array}{c}1088 . \\
4\end{array}$ & $\begin{array}{c}1088 . \\
4\end{array}$ & $\begin{array}{c}1088 . \\
4\end{array}$ & $\begin{array}{c}1088 . \\
4\end{array}$ \\
\hline $\begin{array}{l}\text { SFEFWT } \\
(\%)\end{array}$ & - & 0 & 0.25 & 0.50 & 0.75 & 1 \\
\hline $\begin{array}{l}\text { Fly Ash } \\
\left(\mathrm{kg} / \mathrm{m}^{3}\right)\end{array}$ & - & $\begin{array}{c}58.56 \\
0\end{array}$ & $\begin{array}{c}58.56 \\
0\end{array}$ & $\begin{array}{c}58.56 \\
0\end{array}$ & $\begin{array}{c}58.56 \\
0\end{array}$ & $\begin{array}{c}58.56 \\
0\end{array}$ \\
\hline
\end{tabular}

3) Testing of Specimens: Compressive and splitting tensile tests are conducted on cylindrical specimens using universal testing machine (UTM), and flexural tests are conducted on beam specimens using flexural testing machine in the concrete laboratory of Semen Padang Factory, Padang, as per SNI 1974:2011, ASTM C 496-86 and ASTM C 293-08, respectively. Figs. 6, 7 and 8 show the specimens under compressive, splitting tensile and flexural testing in the laboratory.

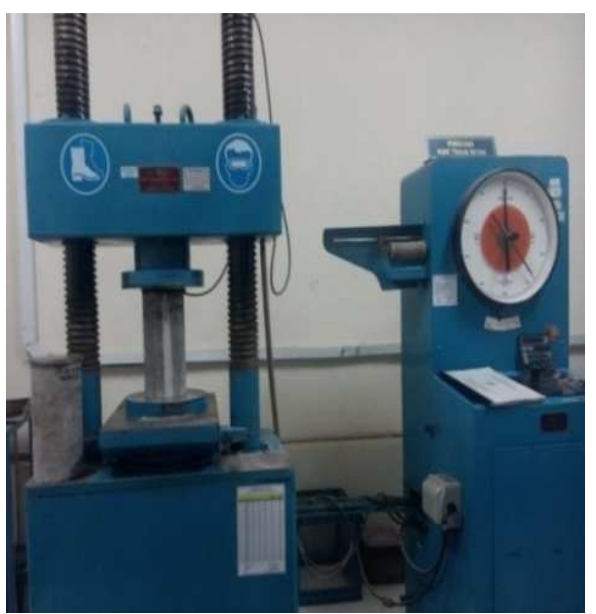

Fig. 6 Compressive test on cylinder

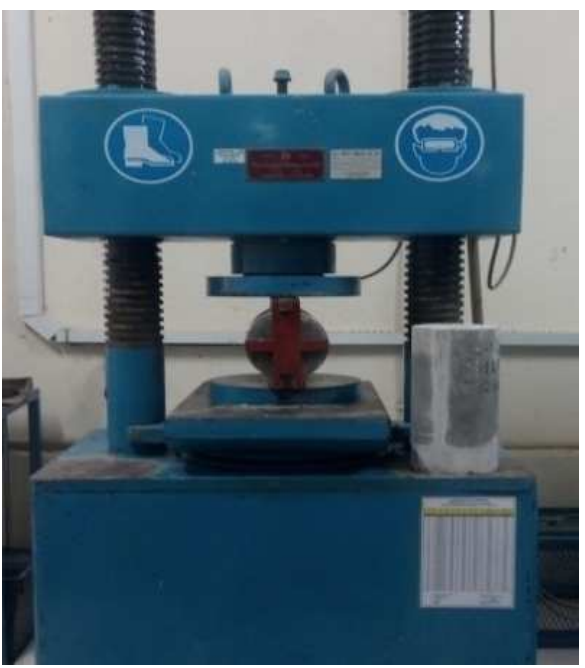

Fig. 7 Splitting tensile test on cylinder

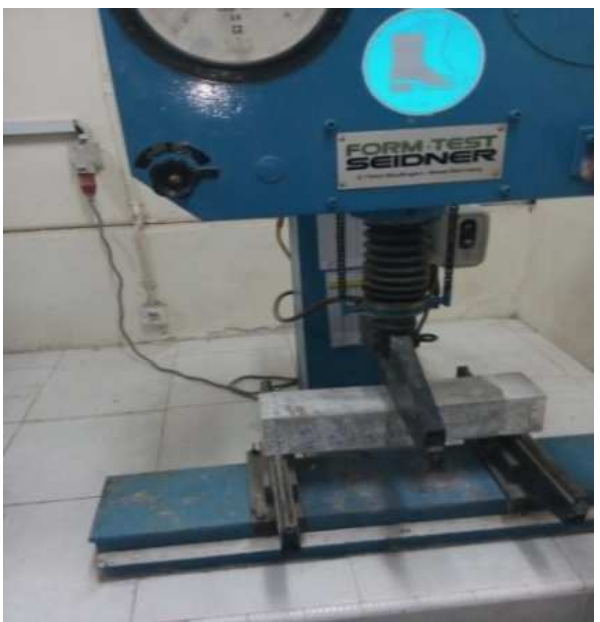

Fig. 8 Flexural test on beam 


\section{RESULT AND DISCUSSION}

\section{A. Compressive Strength}

The results of the tests for compressive strength performed on the samples are shown in Table 3.

TABLE III

28 DAY COMPRESSIVE STRENGTH OF CYLINDRICAL SPECIMENS

\begin{tabular}{|c|c|c|c|}
\hline No. & $\begin{array}{c}\text { Fly Ash } \\
\text { Content } \\
(\%)\end{array}$ & $\begin{array}{c}\text { (SFEFWT) } \\
\text { Content } \\
(\boldsymbol{\%})\end{array}$ & $\begin{array}{c}\text { Compressive } \\
\text { Strength } \\
\left(\mathbf{N} / \mathbf{m m}^{2}\right)\end{array}$ \\
\hline 1 & 15 & 0 & 31.90 \\
\hline 2 & 15 & 0.25 & 32.40 \\
\hline 3 & 15 & 0.50 & 32.90 \\
\hline 4 & 15 & 0.75 & 33.50 \\
\hline 5 & 15 & 1.00 & 33.90 \\
\hline
\end{tabular}

*SFEFWT: Steel Fiber Extracted From Waste Tyre

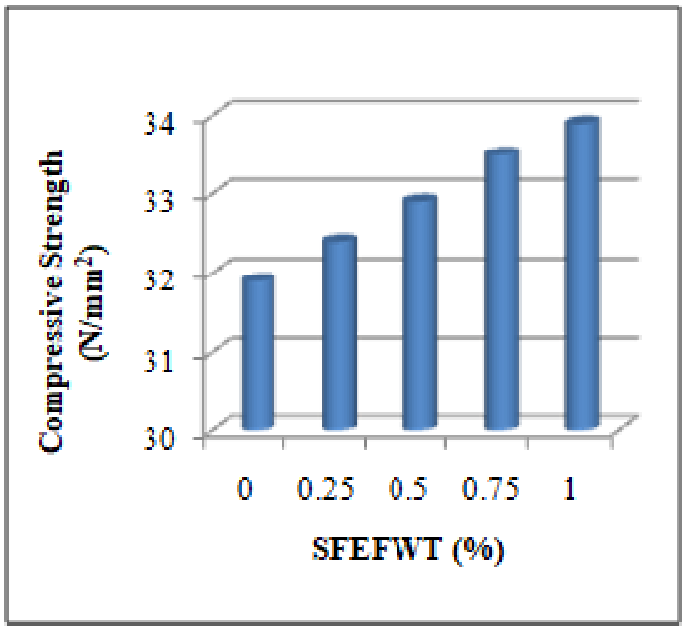

Fig. 9 Comparison of compressive strength of ordinary and SFEFWT FA concrete

Compressive strength of fly ash (FA) concrete mixes which made of SFEFWT is determined at the age of 28 days. It is seen from the results presented in Table 3 and Fig. 9 that the compressive strength of FA concrete reinforced with SFEFWT slightly increases as well as SFEFWT content. The maximum $6.27 \%$ increase, i.e. $33.90 \mathrm{~N} / \mathrm{mm}^{2}$ as compared to concrete without having SFEFWT FA; in addition of $1.0 \%$, SFEFWT is observed. This indicates that there is no significant influence of SFEFWT on compressive strength fly ash concrete.

\section{B. Splitting Tensile Strength}

The results of splitting tensile strength of FA concrete mixed with SFEFWT measured on the 28th day are given in Table 4 and Fig. 10. Test results indicate that the tensile splitting strength increases as the percentage of the SFEFWT on fly ash concrete from $0 \%$ to $0.25 \%, 0.75 \%$, and $1 \%$. This might be in consequence of the strong mechanical interlocking force in concrete due to the present SFEFWT. It is found that the maximum splitting tensile strength on FA concrete by adding $1.0 \%$ SFEFWT is $3.28 \mathrm{~N} / \mathrm{mm} 2$, which is $21.93 \%$ increase as compared to FA concrete without SFEFWT.
TABLE IV

28 DAy INDIRECT TENSILE STRENGTH OF CYLINDRICAL SPECIMENS

\begin{tabular}{|c|c|c|c|}
\hline No. & $\begin{array}{c}\text { Fly Ash } \\
\text { Content } \\
(\%)\end{array}$ & $\begin{array}{c}\text { (SFEFWT) } \\
\text { Content } \\
(\%)\end{array}$ & $\begin{array}{c}\text { Splitting } \\
\text { Tensile } \\
\text { Strength } \\
\left(\mathbf{N} / \mathbf{m m}^{2}\right)\end{array}$ \\
\hline 1 & 15 & 0 & 2.69 \\
\hline 2 & 15 & 0.25 & 2.76 \\
\hline 3 & 15 & 0.50 & 2.86 \\
\hline 4 & 15 & 0.75 & 2.91 \\
\hline 5 & 15 & 1.00 & 3.28 \\
\hline
\end{tabular}

*SFEFWT: Steel Fiber Extracted From Waste Tyre

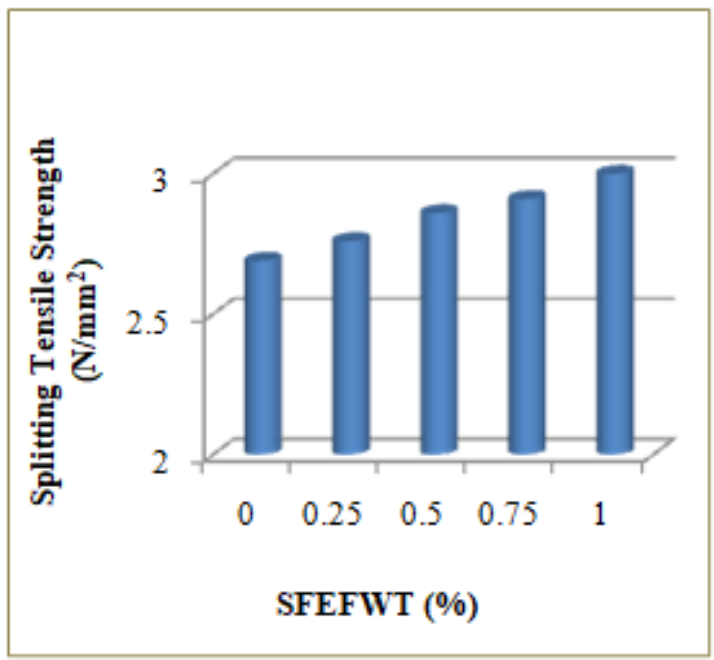

Fig. 10 Comparison of splitting tensile strength of ordinary and SFEFWT FA concrete

\section{Flexural Strength}

The results of the tests for flexural strength performed on the samples are shown in Table 5.

TABLE V

28 Day Flexural Strength of Cylindrical Specimen

\begin{tabular}{|c|c|c|c|}
\hline No. & $\begin{array}{c}\text { Fly Ash } \\
\text { Content } \\
(\boldsymbol{\%})\end{array}$ & $\begin{array}{c}\text { (SFEFWT) } \\
\text { Content } \\
(\boldsymbol{\%})\end{array}$ & $\begin{array}{c}\text { Flexural } \\
\text { Strength } \\
\left(\mathbf{N} / \mathbf{m m}^{2}\right)\end{array}$ \\
\hline 1 & 15 & 0 & 5.24 \\
\hline 2 & 15 & 0.25 & 5.60 \\
\hline 3 & 15 & 0.50 & 5.72 \\
\hline 4 & 15 & 0.75 & 5.83 \\
\hline 5 & 15 & 1.00 & 5.94 \\
\hline
\end{tabular}

*SFEFWT: Steel Fiber Extracted From Waste Tyre

Flexural strength of FA concrete mixes which made of SFEFWT is determined on the $28^{\text {th }}$ day. As shown in Table 5 and Fig. 11, the flexural strength of FA concrete reinforced with SFEFWT increases with the increase SFEFWT content in the FA concrete. The maximum flexural strength 5.94 $\mathrm{N} / \mathrm{mm}^{2}$ is obtained by adding $1.0 \%$ SFEFWT, in which the maximum percentage increase of the flexural strength is $13.36 \%$. The higher results of flexural strength on FA concrete by adding SFEFWT might be due to the fact that the steel fibers will effectively hold the microcracks in concrete mass. 


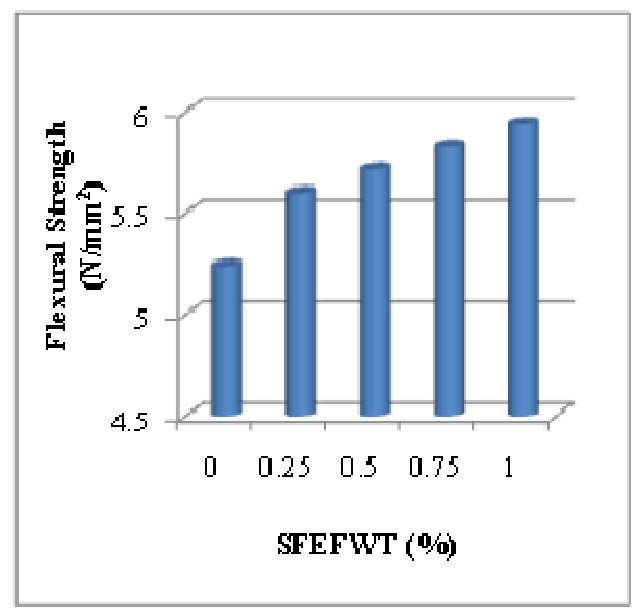

Fig. 11 Comparison of flexural strength of ordinary and SFEFWT FA concrete

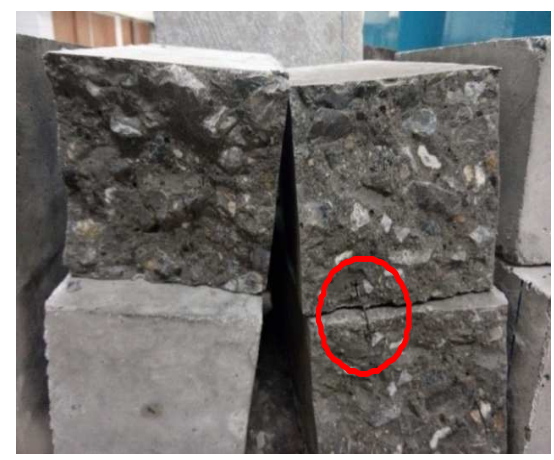

Fig. 12 Crack growth on concrete

The addition of SFEFWT on FA concrete also affected the crack growth of the concrete during the flexural test. The SFEFWT presence controls the crack opening width of FA concrete, in which the fiber bridge across the cracked matrix, so it will bond the concrete together, as shown in Fig. 12. More percentage of SFEFWT on FA concrete gives a high number of bonding in the concrete to delay the crack growth.

\section{CONCLUSION}

The followings are the conclusion of the discussions: Compressive, splitting tensile and flexural strength of FA concrete specimens with steel fiber extracted from the waste tyre (SFEFWT) are found to be stronger than those without having SFEFWT. All concrete investigated, the maximum of compressive strength $6.27 \%$ increase, i.e., $33.90 \mathrm{~N} / \mathrm{mm}^{2}$ as compared to without having SFEFWT concrete; in addition $1.0 \%$ SFEFWT of concrete containing fly ash. The maximum splitting tensile strength with the addition $1.0 \%$ of SFEFWT in concrete containing fly ash is $3.28 \mathrm{~N} / \mathrm{mm}^{2}$, which is $21.93 \%$ increment as compared to conventional concrete. For flexural strength, the maximum $13.36 \%$ increase, i.e., $5.94 \mathrm{~N} / \mathrm{mm}^{2}$ is observed at addition $1.0 \%$ SFEFWT as compared to the concrete without having SFEFWT. The SFEFWT presence controls the crack opening width of FA concrete, in which the fiber bridge across the cracked matrix, so it will bond the concrete together. More percentage of SFEFWT on FA concrete gives a high number of bonding in the concrete to delay the crack growth.

\section{ACKNOWLEDGMENT}

The authors would like to acknowledge the staffs of The Material and Structure Laboratory of Andalas University and The Concrete Laboratory of Padang Cement Factory for their support.

\section{REFERENCES}

[1] Y. Mohammadi, Singh SP, Kaushik SK, "Properties of steel fibrous concrete containing mixed fibers in fresh and hardened state", Constr Build Mater 2006; doi:10.1016/j.conbuildmat.2006.12.004.

[2] M. Jalal, "Compressive Strength Enhancement of Concrete Reinforced by Waste Steel Fibers Utilizing Nano SiO2", MiddleEast Journal of Scientific Research, 12 (3): 382-391, ISSN: 19909233, 2012.

[3] T.C. Yet, R. Hamid, and M. Kasmuri, "Dynamic Stress-Strain Behavior of Steel Fiber Reinforced High-Performance Concrete with Fly Ash", Hindawi Publishing Corporation, Advances in Civil Engineering vol. 2012, Article ID 907431, 6 pages, 2012.

[4] Abbas AL-Ameeri, "The Effect of Steel Fiber on Some Mechanical Properties of Self Compacting Concrete", American Journal of Civil Engineering. Vol. 1, No. 3, PP. 102-110, Nov 10, 2013.

[5] Abhishek Sachdeva and Pankaj Singla, "Strength Evaluation of Steel Fiber Reinforced - Self Compacting Concrete", International journal of Engineering Research \& Technology, ISSN: 2278-0181 VOL.4, Issue September 9, PP. 834-837, 2015.

[6] G.S. Luca, Meda, A. and A. P, Giovanni, "Steel Fiber Concrete Slabs on Ground: A Structural Matter", ACI Structural Journal, Vol 103, PP 551-558, 2006.

[7] M. Nili, V. Afroughsabet, "Combined effect of silica fume and steel fibers on the impact resistance and mechanical properties of concrete" International Journal of Impact Engineering, Vol 37, PP 879-886, 2010.

[8] O. Gencel, W. Brostow, T. Datashvili, and M. Thedford, "Workability and Mechanical Performance of Steel Fiber-Reinforced Self Compacting Concrete with Fly Ash”, Composite Interfaces, Vol 18, pp 169-184, 2011.

[9] M.C. Nataraja, T.S. Nagaraj, and S.B. Basavaraja, "Reproportioning of steel fibre reinforced concrete mixes and their impact resistance", Cement and Concrete Research, Vol 35, PP 2350-2359, 2005.

[10] Li Yijin, Zhou Shiqiong, Yin Jian and Gao Yingli, "Effects Of Fly Ash on The Fluidity of Cement Paste, Mortar and Concrete", International workshop on sustainable development and concrete technology, Central South University, PRC, PP.339-345, 2009.

[11] N. Bouzoubaâ1, M. H. Zhang and V. M. Malhotra1, "Mechanical Properties And Durability Of Concrete Made With High-Volume Fly Ash Blended Cements Using A Coarse Fly Ash”, 2004.

[12] S.K. Das and Yudhbir, "eotechnical Characterization of Some Indian Fly Ashes", Journal of Materials in Civil Engineering, Vol. 17 No. 5, PP. 546, 2005.

[13] R. Siddique, "Properties of concrete incorporating high volumes of class F fly ash and san fibers". Cement Concrete Res, 34:37-42, 2004.

[14] I.B. Topcu, M. Canbaz, "Effect of different fibers on the mechanical properties of concrete containing fly ash". Constr Build Mater, 21:1486 - 91, 2007.

[15] Pilakoutas, K, Neocleous, K and Tlemat, H, "Reuse of Tyre Steel Fibers as Concrete Reinforcement", Proceeding of the ICE: Engineering sustainability, 157(3), pp. 131-138, 2004.

[16] Y. Mohammadi, R. Carkon-Azad, Singh, S.P and Kaushik, S.K, "Impact resistance of steel fibrous concrete containing fibers of mixed aspect ratio”, Construction and Building materials, Vol 23, pp. 183-189, 2009. 